\title{
Identifying game elements suitable for MOOCs
}

\author{
Citation for published version (APA):
}

Antonaci, A., Klemke, R., Stracke, C. M., \& Specht, M. (2017). Identifying game elements suitable for MOOCs. In É. Lavoué, H. Drachsler, K. Verbert, J. Broisin, \& M. Pérez-Sanagustín (Eds.), Data Driven Approaches in Digital Education: 12th European Conference on Technology Enhanced Learning, EC-TEL 2017, Tallinn, Estonia, September 12-15, 2017, Proceedings (pp. 355-360). Springer. Lecture Notes in Computer Science (LNCS) series Vol. 10474 https://doi.org/10.1007/978-3-319-66610-5_26

\section{DOI:}

10.1007/978-3-319-66610-5_26

Document status and date:

Published: 01/09/2017

Document Version:

Peer reviewed version

\section{Document license:}

CC BY-NC-SA

Please check the document version of this publication:

- A submitted manuscript is the version of the article upon submission and before peer-review. There can be important differences between the submitted version and the official published version of record. People interested in the research are advised to contact the author for the final version of the publication, or visit the DOI to the publisher's website.

- The final author version and the galley proof are versions of the publication after peer review.

- The final published version features the final layout of the paper including the volume, issue and page numbers.

Link to publication

\section{General rights}

Copyright and moral rights for the publications made accessible in the public portal are retained by the authors and/or other copyright owners and it is a condition of accessing publications that users recognise and abide by the legal requirements associated with these rights.

- Users may download and print one copy of any publication from the public portal for the purpose of private study or research.

- You may not further distribute the material or use it for any profit-making activity or commercial gain

- You may freely distribute the URL identifying the publication in the public portal.

If the publication is distributed under the terms of Article 25fa of the Dutch Copyright Act, indicated by the "Taverne" license above, please follow below link for the End User Agreement:

https://www.ou.nl/taverne-agreement

Take down policy

If you believe that this document breaches copyright please contact us at:

pure-support@ou.nl

providing details and we will investigate your claim.

Downloaded from https://research.ou.nl/ on date: 26 Apr. 2023 
PRE-PRINTED COPY

Antonaci, A., Klemke, R., Stracke, C. M., \& Specht, M. (2017). Identifying Game Elements Suitable for MOOCs. In É. Lavoué, H. Drachsler, K. Verbert, J. Broisin, M. Pérez-Sanagustín (Eds.), Data Driven Approaches in Digital Education: Proceedings of 12th European Conference on Technology Enhanced Learning EC-TEL 2017 (pp. 355-360). Cham: Springer. https://doi.org/10.1007/978-3-319-66610-5

\title{
Identifying game elements suitable for MOOCs
}

\author{
Alessandra Antonaci ${ }^{1}$, Roland Klemke ${ }^{1}$, Christian M. Stracke ${ }^{1}$ and Marcus Specht ${ }^{1}$ \\ ${ }^{1}$ Welten Institute - Research Centre for Learning, Teaching and Technology, Open University \\ of the Netherlands, P.O. Box 2960, 6401 DL Heerlen, The Netherlands \\ alessandra.antonaci@ou.nl, roland.klemke@ou.nl, \\ christian.stracke@ou.nl, marcus.specht@ou.nl
}

\begin{abstract}
Massive Online Open Courses (MOOCs) have increasingly become objects of research interest and studies in recent years. While MOOCs could be a means to address massive audiences, they suffer from high drop-out rates and low user engagement. Gamification is known as the application of game design elements in non-gaming scenarios to solve problems or to influence a user's behaviour change. By applying gamification to MOOCs, we aim to enhance users' engagement and goal achievement within a MOOC environment. To define our gamification strategy, we asked 42 experts in the fields of game design, learning science and technology-enhanced learning to rate 21 selected game design patterns according to their suitability within a MOOC environment application. The data collected allowed us to identify a set of nine game design patterns as promising candidates to be tested in MOOC environments.
\end{abstract}

Keywords: Gamification, Game Design Patterns, MOOCs, Quantitative, Qualitative, Data, Analysis

\section{Introduction}

Despite their recent success in reaching mass audiences [1] and their potential to deliver education to the majority of world inhabitants [2], Massive Online Open Courses (MOOCs) in their current form also suffer from several drawbacks, including low completion rates [3] and lack of participants' engagement [4].

Gamification is a well-known phenomenon in Technology-Enhanced Learning (TEL) [5]. However, examples of gamified MOOCs that aim at overcoming the lack of user engagement as well as increasing completion rates via the design of paths that allow users to pursue and achieve their goals are currently sparse [6]. One of the first empirical studies aiming at investigating gamification in MOOCs can be found in [7]. It identifies 40 suitable game mechanics to engage students in MOOCs, of which 10 game mechanics with the highest level of engagement (virtual goods; three different 
types of points; leader boards; trophies and badges; peer grading and emoticon feedback; two types of games) where selected in an online survey with 5,020 participants [7]. The study did, however, not consider the game designer's perspective and furthermore the level of engagement of these game mechanics was defined based on users' self-perception, not on an empirical basis.

The purpose of this paper is to present a study aiming at identifying a suitable set of Game Design Patterns (GDPs) ${ }^{1}$ to be applied to and tested in a MOOC environment to enhance learners' engagement, goal achievement, and learning performance. We first study the literature related to the type of game elements generally used to design and implement gamification [8]. Particularly, nine elements are most used and often aim at stimulating users' behaviour change playing on external rewards [9]. We complemented these findings by consulting the game design pattern collection of Björk and Holopainen [10]. This collection represents a resource of 200 GDPs designers, each of them described by name, description, consequences, implication in using the pattern and relations with others GDPs.

To pre-select candidates for gamification in MOOCs the collection of GDPs compiled from literature and the pattern collection in [10] was scrutinised based on the following inclusion criteria: (1) the frequent use of a GDP in literature, (2) the applicability of a GDP in a multi-user environment, and (3) our hypothesised impact of the selected pattern on learners' engagement, goal achievement, or learning performance. As a result, the following 21 GDPs were selected from these collections and presented to 42 experts to be validated: (1) Avatars/Characters; (2) Time Limits; (3) Levels; (4) Communication Channels; (5) High Score Lists; (6) Score; (7) Status Indicators; (8) Public Information; (9) Story Telling; (10) Rewards; (11) Goal Indicators; (12) Stimulated Planning; (13) Clues; (14) Cooperation; (15) Limited Planning Ability; (16) Competition; (17) Team Play; (18) Replayability; (19) Smooth Learning Curves; (20) Handicaps; (21) Empowerment.

The experts involved in this study are game designers, learning scientists and TEL experts. The game designers were included for their expected ability to evaluate effects of specific GDPs in a given scenario; the learning scientists to judge the GDPs from a didactic and educational perspective; and the TEL experts to evaluate both perspectives and rate applicability and feasibility of the GDPs chosen.

The remainder of this paper is organised as follows: first the methods used are explained; secondly the participants and the procedures are presented; thirdly a summary of the quantitative and qualitative data are detailed and our conclusions drawn.

\section{Game Design Pattern Evaluation Study}

Methods. Two methods were used to assess the GDPs selected for designing a gamified MOOC: a survey and a focus group. The survey was designed to validate our GDPs selection and to collect feedback from our target population. The GDPs pro-

\footnotetext{
${ }^{1}$ In this paper the terms game elements, game mechanics and game design patterns are used as synonymous even if the authors are aware of their differences.
} 
posed to our audience population were rated according to designing a MOOC with one of the three following gamification purposes ( $g p \mathrm{~s})$ in mind: $g p 1$. Enhancing learning performance; g $p 2$. Enhancing goal achievement; gp3. Enhancing engagement. Secondly, the focus group was conducted for game designers to conceptualize a gamified MOOC using the GDPs deemed most relevant for the selected gamification purpose.

Participants. A total of 42 subjects took part in our study: 17 game designers; 9 learning science experts and 16 TEL experts. The subjects decided individually on which of the three gamification purposes $(g p 1-g p 3)$ they wanted to focus. Six of the game designers worked on $g p 1$; six on $g p 2$ and five on $g p 3$. Four learning scientists, worked on $g p 1$; three on $g p 2$ and two on $g p 3$. Five TEL experts focused on $g p 1$; four on $g p 2$ and seven on the $g p 3$.

Procedures. Participants were introduced to "MOOCs" and "Gamification". The game designers were invited to take part in the focus group as part of a game design workshop and were divided into six groups assigned to the three intervention purposes $g p 1-g p 3$ (two groups for each purpose). The topic of the MOOC was predefined as cyber-security. Each group elaborated a concept that was presented to the other colleagues. The data of the focus group are detailed in the results paragraph under the qualitative section. All participants filled out the survey, comprising 2 questions for each of the 21 GDPs selected: a closed question, rating the GDPs in relation to the purpose selected ( $g p 1-g p 3)$ using a scale from 0 ("strongly negative effect") to 4 ("strongly positive effect"). The second question for each GDP was optional and open; here participants could detail the advantages and/or disadvantages of using the given GDP for the specific purpose.

\section{$3 \quad$ Results}

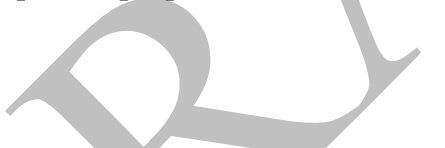

The experts' evaluation. Table 1 shows the results related to the quantitative data collected with the questionnaires according to the three gamification purposes $g p 1$ gp3.

Table 1. Sample GDP selection based on the average score $(x)$

\begin{tabular}{|c|c|c|c|c|c|c|}
\hline Experts & $\begin{array}{l}\text { Game Designers' } \\
\text { GDP Selection }\end{array}$ & $x$ & $\begin{array}{c}\text { Learning Scientists' } \\
\text { GDP selection }\end{array}$ & $x$ & $\begin{array}{l}\text { TEL experts' GDP } \\
\text { selection }\end{array}$ & $x$ \\
\hline \multirow{3}{*}{$\begin{array}{l}g p 1 \text { - enhancing } \\
\text { MOOC users' } \\
\text { learning perfor- } \\
\text { mance }\end{array}$} & \multirow[b]{2}{*}{$\begin{array}{l}\text { Communication } \\
\text { Channels }\end{array}$} & \multirow[b]{2}{*}{3.83} & Levels & 4 & \multirow{2}{*}{$\begin{array}{l}\text { Levels, Smooth } \\
\text { Learning Curve }\end{array}$} & \multirow[b]{2}{*}{3} \\
\hline & & & Empowerment & 3.75 & & \\
\hline & $\begin{array}{l}\text { Cooperation, Replay- } \\
\text { ability and Smooth } \\
\text { Learning Curves }\end{array}$ & 3.5 & $\begin{array}{l}\text { Avatar/Characters, } \\
\text { Storytelling and } \\
\text { Clues }\end{array}$ & 3.5 & $\begin{array}{l}\text { Storytelling, Re- } \\
\text { playability and } \\
\text { Empowerment }\end{array}$ & 2.8 \\
\hline \multirow{3}{*}{$\begin{array}{l}\text { gp2 - enhancing } \\
\text { MOOC users' } \\
\text { goal achievement }\end{array}$} & Goal Indicators & 3.67 & \multirow{2}{*}{$\begin{array}{l}\text { Smooth Learning } \\
\text { Curve }\end{array}$} & \multirow[t]{2}{*}{4} & Goal Indicators & 4 \\
\hline & Empowerment & 3.6 & & & Levels & 3.5 \\
\hline & $\begin{array}{l}\text { Communication } \\
\text { Channels }\end{array}$ & 3.5 & $\begin{array}{l}\text { Clues and Empower- } \\
\text { ment }\end{array}$ & 3.67 & $\begin{array}{l}\text { Replayability and } \\
\text { Smooth Learning } \\
\text { Curves }\end{array}$ & 3.25 \\
\hline
\end{tabular}




\begin{tabular}{|c|c|c|c|c|c|c|}
\hline \multirow{2}{*}{$\begin{array}{l}\text { gp3 - enhancing } \\
\text { MOOC users' } \\
\text { engagement }\end{array}$} & $\begin{array}{l}\text { Smooth Learning } \\
\text { Curves }\end{array}$ & 4 & \multirow{2}{*}{$\begin{array}{l}\text { Storytelling, Clues } \\
\text { and Empowerment }\end{array}$} & \multirow[b]{2}{*}{4} & \multirow{2}{*}{$\begin{array}{l}\text { Communication } \\
\text { Channels, Score, } \\
\text { Goal Indicators, } \\
\text { Cooperation and } \\
\text { Smooth Learning } \\
\text { Curves }\end{array}$} & \multirow[b]{2}{*}{3.43} \\
\hline & $\begin{array}{l}\text { Communication } \\
\text { Channels and Re- } \\
\text { wards }\end{array}$ & 3.8 & & & & \\
\hline
\end{tabular}

Hints from Game Design Experts' Focus Group. Each group of game designers was invited to conceptualise the design of a gamified MOOC selecting, based on their experience, the most suitable game elements according to $g p 1, g p 2$, or $g p 3$.

The game elements proposed by the two groups that worked on $g p 1$ were: collaboration via wiki and forum, aiming at developing a sense of community and information sharing, track of personal progress, levels and different levels of tasks, with a rewarding system for their completion and an inventory for personal notes, in which to save helpful posts from the community forum, plus they thought of implementing a game itself within the MOOC. Autonomous path, as well as a collaborative path, that could be enabled by the creation of alliance, asymmetrical information distribution for the solution of boss tests. A skills tree, a game element often present in roleplaying games, (the Diablo ${ }^{2}$ series made it famous) enables custom configurations of a character's abilities. Once the basic skills are gained by the users, it opens several branches and the user can choose the path to follow.

The two groups focussing on $g p 2$ suggested the following game elements: "personal profiles that can be shared with others, badges as reward, progress bar and autonomy". As well as to transfer MMORPG (Massive Multiplayers Online Role Play Games) elements into MOOC, such as: Skill tree, "Knowledge inventory (completed tasks for the course); Overview (whole offer, progress per Skill tree) Co-op (Cooperation with "Classes"); PVP (Player vs Player "Knowledge Battle"); Reward inside of System (Skill tree, Knowledge Inventory, Succeeded Students as mentor for newbies); Reward: outside of Systems (Achievements, Link to LinkedIn)".

Finally, two groups considered the following game elements for gp 3 : competition, collaboration and immediate feedback as, as well as online quizzes for two players, stimulating social comparison and students' engagement, by sending the same question to both and the one who replies faster and correctly wins. Other game elements proposed were: Quests, Narrative, Player/Character, Enemy/Boss, Community (Guild)/ Community Experience and Status Parameter. In particular, the narrative concept consists of "some sort of opposing power that threatens the participants' characters and their private information". "The player needs to use what s/he learns in the modules of the course to contribute to the success of this resistance". Being part of this resistance could help in developing "a sense of community similar to MMORPG communities such as guilds". Therefore "even if participants are working alone, they should feel like they are contributing to the cause of the resistance/ the community".

Hints from Learning Scientists and TEL experts. Learning Scientists (LS), as the TEL experts, were not involved in a focus groups, however they could express their point of view through the use of the open questions contained in the survey that asked

\footnotetext{
${ }^{2}$ Blizzard production, 1998. http://eu.blizzard.com/en-gb/games/
} 
them to detail the advantages and disadvantages of using a specific GDP for the purpose selected. Chosen comments are reported here to give a better overview of the LS and TEL experts' perception on gamification applied to MOOC.

As it is possible to derive from data, the LS indicate with a high score the GDP Clues for the three purposes, as well as Empowerment. While Storytelling was ranked high for $g p 2$ and $g p 3$. Among others Empowerment was appreciated because "people like to have autonomy" and "it can help users to positively achieve their learning goals. While Clues to stimulate the $g p 1$ given only at request ("hints button") "could be useful". For $g p 2$, LS said that Clues, can work as "scaffolding for learners who need a little more support, through clues everybody can achieve their goals", as disadvantages foreseen: "If it is too easy to attain clues, the students might not try to figure things out themselves". While for the gp 3 Clues expert commented: "It helps to have clues, especially for complex goals. However, having them pop up can also be distractive" for users and be a disadvantage.

The TEL experts ranked with a high score the GDPs: Smooth Learning Curves $(S L C)$ for all 3 purposes; Goal Indicators for $g p 2$ and $g p 3$. SLC received the following comments: "If a learner is an international learner who struggles with language or novice learner, it may help them through the course; it could "avoiding discouragement" among users. SLC could have as an advantage the decrease of users' "frustration and boredom" but as a disadvantage the TEL expert raises the problem that it is "hard to design". The game element Goal Indicators was perceived in relation to gp2 as to "provide useful insight about a learner's performance and may set the pace of the learning progress", it could especially be useful "as goals might change over time", while for $g p 3$ considering that "the success is not defined in MOOCs. One might want to finish only the two weeks that they are interested in. So, if that person puts those goals beforehand, and completing them makes that person successful in the course. I think this is very much suitable for the nature of MOOCs".

Comparing LS and TEL experts for GP1 they both highly rated the GDPs: Levels, Empowerment and Storytelling. For gp 2 TEL and LS experts ranked highly the GDP: Smooth Learning Curves. For gp 3 there are no common GDPs with high score.

Considering the similarity among the groups in ranking the GDPs, game designers and LS experts have the GDP Empowerment chosen for $g p 2$ and none for $g p 1$ and gp3. Game designers and TEL experts issued high ratings GDP for gp1 was Smooth Learning Curves; while for gp2 Goal Indicators; and for gp 3 Communication Channels and Smooth Learning Curves.

\section{Discussion, Conclusion and Future Work}

With the aim of identifying suitable GDPs to design our gamification strategy to be applied in a MOOC to enhance users' goal achievement and engagement, we analysed the literature and other sources, in particular Björk and Holopainen's GDPs collection [10]. Our selection was evaluated by experts in several domains: game design, learning science and technology enhanced learning. 
Investigating the point of view of game designers, learning scientists and TEL experts on the selection made, allows us to understand that despite the different backgrounds of our study participants, there are several points of agreement. Table 1 represents in synthesis the most ranked GDPs by purpose and group of experts.

From our quantitative and qualitative data analysed we can deduce that the following game elements are eligible for further testing within MOOCs:

- For gp 1: Empowerment, Smooth Learning Curves and Communication Channels;

- For gp2: Levels, Clues, Communication Channels, Smooth Learning Curves, Goal Indicators and Skills tree,

- For gp3: Guild, Skills tree, Storytelling.

We plan to test with formative and summative studies the above-mentioned GDPs, analyse the effects of gamification on MOOC users' behaviour and evaluate whether our assumptions were correct.

Acknowledgments. This study is partly funded by the I SECURE - Empowering education systems in information security project (n. 2015-1-IT02-KA201-015005) under the Erasmus+ programme of the European Commission. We would like to thank the participants that voluntarily took part in this study.

\section{References}

1. Yousef, A.M.F., Chatti, M.A., Schroeder, U., Wosnitza, M.: What drives a successful MOOC? An empirical examination of criteria to assure design quality of MOOCs. 14th IEEE Int. Conf. Adv. Learn. Technol. ICALT 2014. 44-48 (2014).

2. OECD: Students, Computers and Learning: Making the Connection., PISA (2015).

3. Reich, J.: Learner Intention Recasts "Low" MOOC Completion Rates | HarvardX, http://harvardx.harvard.edu/news/learner-intention.

4. Cook, S., Bingham, T., Reid, S., Wang, L.: Going massive: Learner engagement in a MOOC environment. (2015).

5. Nah, F.F., Zeng, Q., Telaprolu, V.R., Ayyappa, A.P., Eschenbrenner, B.: Gamification of Education: A Review of Literature. In: Nah, F.F. (ed.) International Conference on HCI in Business 2014. pp. 401-409. Springer International Publishing (2014).

6. Antonaci, A., Klemke, R., Stracke, C.M., Specht, M.: Gamification in MOOCs to enhance users ' goal achievement. In: Proceedings of IEEE Global Engineering Education Conference (EDUCON 2017), 25-28 April, Athens Greece. IEEE Xplore.

7. Chang, J.W., Wei, H.Y.: Exploring engaging gamification mechanics in massive online open courses. Educ. Technol. Soc. 19, 177-203 (2016).

8. Dicheva, D., Dichev, C.: Gamification in Education: Where Are We in 2015? In: ELearn 2015 - Kona, Hawaii, United States. pp. 1445-1454 (2015).

9. Dicheva, D., Dichev, C., Agre, G., Angelova, G.: Gamification in Education: A Systematic Mapping Study Gamification in Education: A Systematic Mapping Study. Educ. Technol. Soc. 18, 75-88 (2015).

10. Björk, S., Holopainen, J.: Patterns in Game Design. (2005). 